To sum it all up, how can we make our science of government a true science of administration rather than a device for distributing party spoils, and how can we, at the same time, retain and develop those democratic ideals which we have thought worthy of this great nation? Indeed, it may be that we shall very soon be compelled to answer a still more significant question, namely, how well prepared is the government to aid in the substitution of co-operative mediation between producer and consumer for the mediation thus far furnished by business men alone? Those who cannot bear the light had better not lift the veil.

\title{
PROBLEM OF RECONSTRUCTION WITH RESPECT TO URBAN TRANSPORTATION
}

\author{
BY DELOS F. WILCOX, PH.D. \\ New York City
}

\section{$\mathbf{W}^{\mathrm{n}}$}

$\mathrm{E}$ have reached a crisis in the street railway business. The crisis has been hastened by the extraordinary prices of labor and materials and by the scarcity of capital incident to the carrying on of an unprecedented war in an unprecedented way, but its origin lies much farther back. It is doubtful whether the close of the war will restore normal conditions in local transportation, and even if approximately the old conditions should be brought back it will not be easy for the street railways to recover from the severe financial distress of the present time. It is like a long spell of sickness with a man who is past his prime. The street railways may "get around again," but they will "never be quite the same" as they were before. Only the other day at the conference of the American Electric Railway Association in New York city a resolution was introduced by the president of the Milwaukee Electric Railway \& Light Company and referred to the executive committee of the association for consideration and report, setting forth the present status of the street railway industry from the companies' point of view and declaring in favor of the public acquisition and the future public operation and development of the street railways of the country. It cannot be doubted that the street railway companies are suffering from some desperate malady when the cause of municipal ownership begins to get recruits in these high quarters.

THE FIVE-CENT FARE AS THE BASIS OF SPECULATION

The traditional fixed five-cent fare with general free transfer privileges has heretofore been the chief bastion of the speculative line of defense in the street railway business. The municipality, without transit initiative, 
generally without transit powers, has said to the street railway promoter: "Here is a franchise to use our streets. You may charge five cents a ride. Go to it and make what you can." That looked good to the promoter, and so he established a stock and bond factory for the purpose of carrying out his speculation. It must be admitted, I think, that in the development of street railway systems and the corporations which control them in this country, the idea of public service has generally been incidental. The driving force, the motive that has negotiated franchises, engineered leases, consolidations and mergers, and piled Ossa on Pelion in the organization of holding companies, has in the main been the desire for illegitimate profits. I do not refer in this connection to the superintendents of transportation and other members of the operating forces, but rather to the financial magnates who deal in traction securities and exercise ultimate control over street railway policies from the private point of view. These gentlemen reside in the financial centers of the country and in their manipulation of street railway properties represent all the evils of indirect, unregulated, absentee ownership. The application of the gambler's motives to the control and manipulation of street railways has resulted in almost universal overcapitalization, inflated claims of value, and reckless financing. The street railway business is now on the rocks. The speculative régime has proved to be a dismal and deadly failure.

\section{WHAT STREET RAILWAY COMPANIES SEEK TO ACCOMPLISH DURING THE WAR}

In the present era of financial distress, when it is evident that there is no future for speculation in street railway enterprises, the public service corporations are seeking to save themselves by accomplishing three things:

First, the definite abrogation of their contracts with respect to rates and fare limits.

Second, the definite public recognition of their capitalization and earnings prior to the war as not excessive.

Third, the definite shifting of responsibility for wage increases to public agencies, with the corollary that the bill is to be passed on to the ratepayers.

Everybody is sick and tired of the speculative game as applied to urban transit, but there is trouble about the conditions upon which the transition to a new order should be made. The gamblers who have lost are unwilling to pay up and the gamblers who have won are unwilling to give up. The public is being asked to make good past losses as well as to assume future risks. The losers want to usher in a non-speculative règime which shall be dated back for a generation or two, but with respect to losses only. The winners also want a non-speculative régime, 
but they do not want it dated back far enough to make them disgorge past profits to make up for impending deficiiz.

The present status of the street railways is unsatisfactory to all parties. The sky is full of portents for the future. Disaster to the present investors is imminent and perhaps can be averted only in case the public either unwittingly or from a mistaken sense of duty condemns itself to financial servitude time without end.

The general outlines of the situation are fairly distinct. They may be summarized as follows:

\section{PERSISTENT EVILS OF OVERCAPITALIZATION}

(1) Unsound and reckless financing has been characteristic of the street railway business. Overcapitalization is general and the all but universal tendency of the companies is to swell the capital account at every opportunity. Appropriations for the amortization of obsolete and superseded property have been either scant or entirely lacking. For some years past the companies have sought by every possible device to read values into the properties in an effort to justify and support existing overcapitalization instead of reducing the capitalization to fit the values that really exist. Even the control over capitalization exercised by public service commissions has been quite ineffective as a remedy for past evils and only partially effective as a preventive of future ones. The commissions as a rule have no power to compel a reduction of existing capitalization and the new securities issued under public control are thus put upon a par with old securities which represent uncertain values. Even in the issuance of new securities inflation continues to take place through the practice of the commissions in permitting stocks and bonds to be sold at a discount. The financial conditions which of ten seem to make this practice a necessary one have been brought about in large part by the uncorrected overcapitalization which took place prior to the period of public regulation. It is a universal characteristic of overcapitalization that it tends to destroy or impair the credit of the corporation and thus tends to make the financing of capital additions costly, if not impossible. From every point of view overcapitalization is fundamentally unsound. The only way to cure it is to get rid of it. It is hopeless for a company to try to live it down without correcting it. A remedy that merely, applies to future capital additions is no remedy at all. So long as overcapitalization lasts it impairs credit, overloads fixed charges and stimulates controversy between the company and the public. So long as overcapitalization exists every street railway manager has to be double-faced. To the public he must make professions of interest in service. To his financial masters he must prove that his one aim in life is to make the common stock pay dividends. 
INCREASED COSTS OF SERVICE

(2) The street railway business underwent an enormous expansion following the introduction of electricity as a motive power. It was thought that electrical operation would result in such a lowering of the cost of transportation service as to make almost any kind of a street railway profitable. Lines were consolidated, systems extended and service improved. The effects of this expansion were already being felt when the enormous increase in the cost of labor and materials during the war period struck the industry a paralyzing blow. It may be said that the last saw$\log$ that broke the camel's back was the action taken by the War Labor Board in a warding to street railway employes wages that seemed fabulous in this industry and that were in many cases more than the men had asked for. To "the man on the street" the cost of operating street cars has seemed nominal, but even he is beginning to realize that the companies are being hard hit by war conditions. It is, of course, uncertain as to how long existing prices will prevail, but any substantial decrease in wages in the future to correspond with a general lowering of the price level is likely to be a slow and painful operation. The unionization of street railway employes has been going forward rapidly and it is not likely that they will accept radical reductions in pay without a fight. Every strike means at least a temporary disaster to the company and for that reason every company will be slow to force the issue of lower wages even if general labor conditions seem to warrant a reduction.

\section{MORE REVENUES THE INSISTENT DEMAND}

(3) Excessive fixed charges due to overcapitalization and increased operating costs in the present emergency together have eaten up the companies' revenues and left the stockholders exceedingly hungry. Certain economies have been attempted but in most cases their effect is quite insignificant as compared with the increase in expenses. Moreover, some of these economies, such as the skip-stop and the reduction in car schedules, tend to decrease the service to the public and indirectly to reduce traffic and revenues. One-man car operation, which is one of the most promising economies on the program, cannot be effected without considerable delay and the expenditure of considerable sums of money for new or remodeled cars; and the new capital that would thus result in the reduction of expenses cannot readily be had. To ask the street railway companies under present conditions to economize first, and to seek additional revenues later on if necessary, is much like the wholesome practice of compelling a tramp to saw wood before he is given a breakfast. That is all right if he had a good supper the day before, but if he has gone hungry for a week the strict application of the rule may prove to be both cruel and ineffective. At any rate the companies are in a state of mind where they demand more revenues and insist that they must have them at once or stop functioning. 
THE ABROGATION OF FRANCHISE CONTRACTS

(4) Street railways get the bulk of their revenues from fare-paying passengers. If the rate of fare is fixed and unchangeable the only way to increase the revenues from this source is by an increase in traffic. If the cars are already overcrowded or if the people are moving to other communities, the companies see little hope in this direction. For the immediate relief of their financial pains they see no better way than the abrogation of their franchise contracts and the increase of the rates of fare. It has often been charged that contracts between cities and street railway companies are enforced to the letter when their terms go against the public, but that it proves very difficult indeed to enforce them when they go against the companies. At any rate it is a curious spectacle to see the protagonists of vested interests, who have so often invoked the sacred provisions of the federal constitution to enforce the obligations of contracts, now coming before the public service commissions and without even an apology asking that the provisions of their municipal contracts be set aside because they need more money.

An extraordinary development of law and public policy is resulting from these conditions. In some states franchise contracts have been expressly exempted from the control of the commissions, but in general it may be said that where full-fledged public utility laws have been placed upon the statute books, the courts are holding that the commissions have rateregulating powers superior to the provisions of municipal contracts. The theory is a simple one. The first premise is that the state legislature is supreme and that municipalities have no rights or powers which have not been derived from it or which may not be withdrawn by it. The second premise is that the state, in the exercise of its supreme authority, subsequent to the granting of powers to municipalities, has chosen to exercise certain of them itself. It is as if a man were to delegate his son to carry on a certain portion of his business and to authorize him to enter into contracts for the purchase of supplies or for the construction of a new building. The son proceeds to make terms with a contractor. Subsequently, the contractor finds that his contract is unprofitable and desires to be released from certain of its obligations. Instead of going to the son and securing his consent to a modification of the contract, the contractor approaches the "old man" and submits evidence to show that the contract is onerous. Thereupon the father, without consulting the son or securing his consent, exercises his own superior authority and modifies the contract for the benefit of the other party. It is admitted that the father could not modify the contract for the benefit of the son without the contractor's consent, but it is maintained that if he wishes to sacrifice his own interests as represented by his son he may do so, so long as the contractor is willing to modify the agreement. The son is nobody.

This theory as applied to the relations between the legislature and the 
municipalities with respect to the modification of franchise contracts leaves the municipalities without ultimate authority and makes it impossible for them to enter into contracts with public service corporations with any assurance that the contracts can be enforced. The cities do not take kindly to the abstract theory of the law that they have no rights which may not be sacrificed by the legislature without their consent, and the whole purpose of the municipal home rule movement during the past forty years has been to overcome or circumvent this theory. Thesituation is developing, however, so that in many states constitutional home rule provisions have become ineffective with respect to this particular matter. The importance of this development upon the power of municipalities to deal with the street railway problem in an effective and constructive way can hardly be overestimated.

\section{COMPETITION IN A NEW FORM}

(5) It is a particularly interesting development that now, just as we have come to give legal recognition to the theory of monopoly in public utility service, the practical conditions of monopoly which formerly surrounded the street railway business have been considerably modified. Street railways unquestionably render a necessary service to urban communities. It is also unquestionable that they can be operated more economically and can render better service to the public if the business is handled by a single agency in each separate urban community, but the development of private automobiles and of jitney busses has been so great in recent years as to make serious inroads upon the traffic on which the street railways must depend for their financial support. In other words, just as monopoly has received legal recognition, effective competition has been re-established by a different type of vehicle. The effect of automobile and jitney competition upon the present financial condition of the street railways and upon their financial prospects for the future is profound and, even from the public point of view, alarming.

REVERSAL OF POLICY AS TO DEVELOPMENT OF TRAFFIC

(6) With expenses increased, traffic curtailed by competition and increased revenues sỏught through increases in rates of fare, a crucial test is being applied to the street railway industry. If the unit fare is raised from five cents to six cents, this should produce a 20 per cent increase in revenues; if it is raised to seven cents, we should get a 40 per cent increase in revenues; and if raised to eight cents, a 60 per cent increase in revenues. This is on the assumption that the same number of passengers would ride, but the experiments have been made and it has been found that an increase in the rate of fare tends to reduce traffic. Street railway service is indeed a necessity to every large city, but there is a considerable margin of use of streetrailway service in ordinary times which is not a necessary use 
butmerely a convenience. The tendency of the increased fares is to reduce this convenience traffic, which, obviously, is for the most part the short haul traffic, and this is admitted to be the portion of the traffic that is most profitable to the companies. We have, therefore, in the straight increases of fare which have already been allowed to many street railways, and which many others are clamoring for, a tendeney of profound importance, both from the point of view of the financial interests of the street railway business and also from the point of view of the social importance of the street railway service.

Hitherto it has been recognized as a most important element in enlightened street railway policy to adopt all available means for the development and increase of traffic. All progressive companies have looked upon such an increase as beneficial to them, and all public authorities, except the late Mayor Gaynor of New York, have regarded the increase in the riding habit as a normal and healthful concomitant of urban civilization. Now under the stress of financial need the companies have been adopting measures which in fact tend to drive traffic away and to eliminate that portion of it which cannot be regarded as an absolute necessity. We can understand how in time of war when economies of man-power, fuel and equipment are urged upon everybody, an appeal to the public to use the street cars as little as possible might have some basis in sound reason and good public policy. The same may be true in times like these when a plague is in the land and crowded street cars are supposed to be a prolific means of spreading the contagion, but from the companies' point of view a curtailment of the use of the street cars, whether voluntary or involuntary, means a radical change in the financial outlook of the business, and from the public point of view it means a change in its conception of the social value of street railway service. The question is: Do we ride too much? Was Mayor Gaynor right when he sent his cynical reply to the man who complained that the Brooklyn Rapid Transit Company did not heat its cars? The mayor told the man that his proper remedy was to walk, as he did; in that way he could keep warm without any trouble.

As the matter now stands, the straight increase in fares is tending to transform the character of the street railway business from that of a public utility, intended to meet public convenience and give the widest possible public service, to that of a business occupying the streets for the use of a limited portion of the population whose necessity balks at no increase in cost or whose financial ability is unaffected by so insignificant a matter as street railway fares. The situation presents a complex combination of sociological, psychological and economic factors that is putting the intelligence of street railway managers visibly under strain. 
THE ZONE SYSTEM BEING INTRODUCED AS A MEANS FOR INCREASING REVENUES

(7) Up to this time the one-city-one-fare policy has been characteristic of American street railway development. We have all supposed for a generation that this policy was based upon profound considerations of urban development. Specifically, we have thought that it was responsible for the development of the suburbs and the avoidance of congestion. New York city recently pledged some $\$ 250,000,000$ to guarantee the profitableness to the rapid transit companies of a uniform five-cent fare with long rides. But within the last year since the street railway companies have felt the real pinch of poverty and have made aradical increase in revenues the dominating feature of their program, we are seeing the zone system introduced in various forms in many American communities without any real reconsideration of the reasons which we have always supposed were at the basis of our established American policy. Under cover of the Great War, when people are thinking chiefly of events in Europe, it appears that a long-established custom based upon a welldefined public policy is being overthrown, and a new custom hitherto rejected is being substituted for it merely as an incident to the insistent demand of the street railway companies for more revenue, regardless of the consequences.

It may be that the one-city-one-fare policy as hitherto applied in this country is a false and losing policy. It may be that a zone system will be worked out which is entirely consistent with the best ideals of city planning and the social development of urban communities, but if this is so it ought to be determined as the result of a careful investigation and reconsideration of all the factors from the public point of view. The change certainly ought not to be made over night merely as a device for extracting from an unwilling public a larger compensation for the service rendered by street railway companies.

STRIKES AND CIVIC DISORDER AHEAD UNLESS EFFECTIVE MEASURES ARE TAKEN

(8) A street railway strike has usually been a signal for disorder and a reversion to a state of semi-barbarism in the midst of the centers of civilization. That continuity of street railway service should be left to the mercy of contending economic forces, without any public authority to compel peace and performance of functions, has long been recognized as anomalous and dangerous to society. Two years ago attention was sharply directed to the necessity for legislation to prevent strikes among public utility employes and considerable progress was made in the discussion and formulation of plans to that end. When America entered the war, it became a matter of paramount national importance that labor troubles should be minimized and the interruption of vital public serv- 
ices prevented. The War Labor Board was established. It has now been functioning for several months with notable success so far as the settlement of strikes is concerned, but as already noted its awards have greatly accentuated the financial problems of the street railways. Moreover, these awards have raised issues of public policy which were quite beyond the scope of the War Labor Board to settle. We are now face to face with the alternative of providing permanent and effective public machinery for adjusting street railway wages and conditions of work or of risking an era of profound civic dangers due to an unprecedented breakdown of urban transportation service by reason of industrial conflict.

SYSTEMS THAT HAVE GROWN BEYOND MUNICIPAL BOUNDARIES

(9) The enormous difficulty of properly controlling private companies in the operation of street railways has been borne in upon the American public for a generation past, and it must be said that the elaborate and costly experiments which we have made in commission regulation have not convinced the public that the problem has been solved. To these long-recognized difficulties have now been added the financial difficulties of the business from the point of view of the companies themselves. At a time when the logic of events tends more strongly than ever before to public ownership and operation, we are compelled to consider certain practical difficulties which have grown up as an incident of the development of the street railway business under private control. I refer to the expansion of individual street railway systems beyond the limits of the principal municipalities which they serve, so that at the present time comparatively few large street railway systems are operated independently in single urban units.

We still talk of municipal ownership and operation, but the fact that the Public Service Railway Company of New Jersey extends its service to no less than 140 municipalities, and that many companies in New England, Pennsylvania and other portions of the country have similarly expanded their systems, presents very serious difficulties indeed to the practical application of the municipal ownership policy. In many cases the consolidation of companies operating in widely separated cities has gone far beyond the requirements of public service. A separation of these systems into several units under municipal ownership and operation would not be seriously disadvantageous to the public. Yet it must be said that in communities where municipal boundaries have not been consistently expanded to keep pace with urban development, there are many cases where it would be fatal to the efficiency of the street railway service to cut it in two at existing municipal boundary lines. No doubt a plan could be worked out by which the principal municipality in a group served by a single street railway system could become the successor of the company for the ownership and operation or at least for the operation of the 
street railway service both within and without its own corporate limits, but this necessity presents another hurdle for the municipal ownership movement to take. A still more serious difficulty would be met in an effort financially to unscramble the overgrown street railway systems which, for purposes of municipal ownership and operation, should be restored to their original condition of separateness. It must be admitted that many of these systems, as they are now constituted, are about as incongruous as the Austro-Hungarian Empire, but in most cases the street railway Hapsburgs live in Philadelphia or New York. If we are to judge from this analogy, the process of unscrambling the systems will be long and tedious. It is often the despair of intelligent municipal effort that the control of the street railway property has been so enmeshed in a series of complex and more or less secret feudal obligations to absentee overlords as to make it difficult, if not impossible, to reach the parties who have power to enter into a new agreement with the city based upon modern principles.

\section{PUBLIC OPERATION WITHOUT PURCHASE}

(10) Under conditions that prevailed before the war a good many people who favored municipal ownership were opposed to municipal operation. We then had three distinct policies under discussion, namely, (a) private ownership and operation, (b) municipal ownership and private operation and (c) municipal ownership and operation. The conditions arising out of the war and the precedents established by the federal government in connection with the steam railroads and the telegraph and telephone lines, have brought another possible policy prominently into view, namely, (d) private ownership and public operation. This policy has already been adopted in the Boston case, and the financial difficulties in the way of immediate purchase of the street railway lines of the country, coupled with urgency for financial relief of the companies, are likely to bring very substantial support to this policy during the impending reconstruction period. The advantages of retaining unitary operation of large systems which are partly interurban are directing attention to the possibility of state rather than municipal operation. It may be safely assumed that the states are less keenly interested in ownership as such than the municipalities would be. Therefore, we have to consider a set of problems that are new and that are radically different from the problems previously considered in connection with urban transit.

In view of all these conditions, what is to be done with the street railways?

\section{THE SPECULATIVE ELEMENT MUST BE REMOVED}

In the first place, it is agreed that the speculative element in street railway investments must be removed and that the public must get the benefit and bear the burden of service at cost. The simple and obvious means 
of attaining these ends is public ownership and operation, or public operation with private ownership. But besides the difficulties inherent in public operation, which are still terrifying to the majority of people who are in a position to formulate public policies and put them into practical effect, there is the immense difficulty in settling the dispute as to the value of the property for the purposes of the change. Whether the public buys the property outright or merely guarantees an annual return upon its value, it cannot afford to recognize an investment that is grossly excessive. The street railway business is not what it once was. Since the advent of the myriads of automobiles, a city can get along for a few days in a lame sort of way even when the street, cars stop entirely. It is still to be expected that in normal times in well developed urban communities the street railway business can be made to be self-sustaining. But the future is far from rosy. Increases in unit fares and shortened fare zones have a tendency to defeat their own immediate purpose and to stimulate competition to make further inroads upon traffic. This forecasts a radical change in the nature of the street railway as a public utility and in the character of the service it renders The financial results of such a change are extremely dubious. It is apparent that neither under private nor under public management can there be any hopeful future for profit in the urban transit business unless on the basis of the most conservative capitalization. There is absolutely no hope that the mules which were pulling street cars in 1879 and the cables that were scrapped in 1892 will be able to continue indefinitely to earn dividends in the street railway business. They have been outflanked. They should have retired long ago. It looks now like unconditional surrender for them. The only possible salvation of the street railway business as a business lies in the cutting down of capital investments to bed rock value as a first step. The celebrated halo of intangible value caused by the wearing down of new property will have to be blown away and forgotten. The engineers' dreams of overhead percentages designed to make up for deficiencies in the value of visible property will have to be dissipated. Bond discounts reflecting unsound financial arrangements, promoters' profits for securing unprofitable franchises and promoting disastrous consolidations, and many another wraith of the corporation conjurers hired to find values where they do not exist will have to be motioned away when the capital account is being fixed. Perpetual rentals based on franchise values will have to be cut off. I believe that by the use of drastic remedies such as these and by the institution of economies such as one-man car operation, the street railway business may be brought back in normal times to a self-sustaining basis in most large urban communities. But where subways are built in congested streets or suburban lines are extended through the open fields, the net earning power of the business, if proper service is given, will be doubtful even under the best conditions. 
SERVICE MUST BE RENDERED AT COST

In the second place, it is pretty well agreed that, with the removal of the speculative element, street railway service must be rendered at cost. Of course, it is understood that the term "cost" includes the necessary return upon a secured investment and the necessary compensation for competent management. The cost, whatever it is, will have to be paid either by the patrons of the cars or by the general public. As applied to an individual street railway enterprise, this is a corollary of the conclusion that the speculative element shall be removed. As applied to the street railway business generally, it is only another version of the well-known axiom that you cannot eat your cake and still have it to eat. It is the universal law of compensation that the cost of every service must be paid.

WAGES AND CONDITIONS OF LABOR TO BE FIXED AND STRIKES TO BE OUTLAWED.

In the third place, the responsibility for fixing wages and conditions of labor cannot be left as in the old days to the discretion of the employing companies. There is still considerable difference of opinion as to the most feasible solution of this problem. Labor hesitates to give up the right to strike even in services where continuity is essential to the public welfare. But it is intolerable that the public should have no guaranty of service pending the adjustment of labor disputes. In my opinion, the power to fix wages and working conditions will have to be conferred upon the same public bodies which are vested with power to fix rates, and that strikes on street railways will have to be outlawed. This policy involves the participation of public authority in a much more intimate and vital way in the management of the business of urban transportation, and greatly narrows the margin of difference between public control and public operation, but democracy cannot shrink from bearing the essential burdens of governmental responsibility. It has applied for the job of running the public affairs of the world. It must fit itself for the task and take hold.

FIXED FARE AND SUBSIDIES, OR A FLEXIBLE FARE-WHICH?

This brings us to the fourth fundamental question of policy, as to which no clear answer can yet be given. It is this: Shall street car fares be maintained at a fixed low figure, regardless of the cost of service, any deficits being made up out of taxes, or shall fares be flexible and be so adjusted as to place upon the riders the full burden of the cost of service at all times? We used to ask the question: Shall the street railways be operated for profit? That is now obsolete, and we have to deal with the obverse question: Shall street railways be operated at a loss? The issue is fundamentally the same whether we continue private ownership and operation or change to public ownership and operation. If we retain private ownership with a guaranty of an excessive capital value, or if we 
go to public ownership by paying an excessive price, the chances of financial failure are excellent, no matter what rates of fare may be charged. That will break off one horn of the dilemma and leave us with no alterna= tive but to adopt the subsidy plan. But with a conservative capitalization and prudent management, we may hope, in most cases, to be permitted to answer the question on its merits. This is a fundamental question of municipal policy and may give rise to sharp differences of opinion. The one-city-one-fare rule which has prevailed so generally in the United States up to very recent times is generally coupled with the idea that transit should be cheap as well as of uniform price. It has become clear through the experience of metropolitan cities that the area of the uniform fare cannot be indefinitely extended, if the fare is to be kept low and the transit system is at the same time to be self-sustaining. New York city, after having been plagued for more than half a century with intolerable congestion of population, thought it well within the last few years to contribute an enormous sum of money for the express purpose of insuring to its citizens a uniform low rate of fare over a very extended area. Under the dual subway contracts, the city defers receiving any return upon its own investment until all operating expenses and a fixed return upon the capital of the operating companies have been paid. Any deficits are to be made up out of taxes. In other words, New York thought the uniform five-cent fare to be of sufficient social importance to vote it an immense subsidy. On the other hand, in the recent legislation adopted by the state of Massachusetts establishing a board of trustees for the public operation of the Boston Elevated Railway system, it was expressly provided that the trustees should increase the fares to any amount which might be necessary to make the enterprise self-sustaining on the financial basis set forth in the act. It is not yet certain that the board of trustees will be able to fix fares in such a way as to make the system self-sustaining, notwithstanding the requirements of the statute. But at any rate Massachusetts adopted the policy of making the Boston system self-sustaining under all conditions.

\section{"HORIZONTAL ELEVATOR" SERVICE}

The difference between this policy and the one adopted by New York in the dual subway contracts is radical. For my own part, I am inclined to the view that local transit will be recognized more and more as a public function for the general convenience of the people, and that the New York idea rather than the Boston idea will prevail. I am aware that at the present time the trend is toward the adoption of the service-at-cost plan with a fluctuating rate of fare. This is evidenced by the Cleveland street railway settlement of 1910 , the new Montreal tramways contract of 1918 and the traction ordinances recently passed by the city councils of Philadelphia and Chicago, as well as by the action taken by the regu- 
lating authorities in many parts of the country authorizing an increase in street railway fares above the traditional five cents. In my opinion, however, this present tendency will cause a reaction as soon as general conditions become normal again after the close of the war. The resentment against the higher fares and the curtailment of traffic will together tend to bring about a restoration of a low unit fare which in the case of the great cities will be guaranteed by potential subsidies from taxation. I am even inclined to expect that ultimately street railway service in many cities may be treated as what might be called a horizontal elevator service. No owner of an office building would think of charging a fare on the elevators used in ordinary business service. It is only on the special elevators which carry people to the roof for observation purposes that a fare is charged. It is quite possible that in the future the city will regard general convenience of movement within its limits as of sufficient importance to provide transit service free or at a nominal rate. One might think that free transit service would lead to excessive use and thus prove to be an expensive luxury. It is a matter of common observation that the human race is largely made up of persons who enjoy motion for motion's sake. Many prefer jitneys to street cars, apparently because the jitney is an automobile and furnishes the exhilaration of what is still a comparatively novel kind of motion. The habit of riding in the street cars for pleasure has been pretty well broken and there is little likelihood that even if street car service were free on the normal routes of travel in the business districts and between home and work the volume of traffic would be in the long run excessive. Street car motion is no longer so attractive as it once was, as other and newer kinds of motion and excitement are now available.

\section{CONTROL MORE DIFFICULT THAN OPERATION}

We come, lastly, to the question of ownership and operation. It is apparent that we have long since crossed the Rubicon. Street railway service is a public function. The only question left is this: Shall the municipalities or other public bodies perform this function directly, or shall they contract it out to private agencies? In the future, city planning in the broad sense of the term, the development of municipal democracy and the dictates of public policy, rather than the desire for profit, must control. Even if private ownership and operation of transit lines is continued, the problem will be to make private ownership and operation act as if it were public ownership and operation. The fundamental motive that normally actuates private ownership and operation is irreconcilable with the motive that dictates public policy. Both cannot prevail. One must be held in check while the other controls the enterprise. If the return upon private capital is guaranteed and is limited to a fixed annual percentage, then we deprive the business of the alleged benefit of private 
incentive for economy and efficiency and these virtues of mangement will in the long run be developed only through the substitution of minute public control for the normal incentive of profit. It is to be noted, however, that from the public point of view economy is not necessarily advantageous when it interferes with service. In general the public may be more interested in having good service than in having economy of operation where that represents a curtailment of service as to either quantity or quality. Likewise, the public's interest in efficiency is likely to be more from the point of view of service than from the point of view of low cost. Economy and efficiency, therefore, are of unquestioned importance to the public only to the extent that they do not interfere with the desired quantity and quality of service, while from the point of view of a private company economy and efficiency are of importance to the extent that they do not interfere with revenues. The Montreal tramways contract represents what is perhaps the most serious effort thus far made to enlist the co-operation of a private company in the provision of service upon the same basis as if it were actuated by public motives. It is an experiment the outcome of which will be watched with great interest. I cannot escape the conviction, however, that any scheme of public regulation and control which adequately protects the public interest will require greater wisdom and more persistent watchfulness than would be required by direct public ownership and operation. It seems to me that it is easier politically and in every other way for the cities to perform the service which they require than it it is for them to compel or induce private parties to perform it when those private parties are necessarily actuated by motives in conflict with the fundamental motive of the public service. Our experience with public service commissions during the past eleven years has not clearly demonstrated their ability to cope with the problems presented to them in any better fashion than cities which own and operate their utilities have coped and are coping with the problems of public utility administration. I do not mean that municipal administration of public utilities has been an unqualified success in this country; on the other hand, I see that its faults are many and grievous ones. But inherently, it seems to me, the problems of direct ownership and operation are much less subtle and baffling than the problems of adequate public control under private management.

\section{TIME FOR "LIBERALITY" IS PAST}

To sum up the situation, I would say that private speculation in urban transit is generally recognized to be out of date; that the simple and direct way of eliminating speculation is through public ownership and operation; that a less direct and more difficult way is through the negotiation of service-at-cost contracts with the private companies, and that in any case the most difficult and the most fundamental problem to be solved 
now is the determination of the amount to be recognized as the legitimate capital value of the street railway system at the date when the transformation from a speculative to a non-speculative investment is made. In this matter it is absolutely essential from every point of view that a policy of conservatism shall be adopted. People often say that "we can afford to be liberal" in order to get the question settled. The time when cities could afford to be liberal in the establishment of the capital value of street railway systems has passed. No mummies in the pyramids of street railway overcapitalization are old enough to defy the disinteg rating influences of the new financial atmosphere. Liberality is from now on a false watchword. Cities cannot afford to go beyond the dictates of justice, and the sooner this condition is recognized by everybody the more rapid will be our progress toward a solution of the immensely difficult financial problems of urban transit with which we are now confronted. The attitude of municipal liberality, which seems so praiseworthy to many, is at the very basis of the looseness and inefficiency which is charged against municipal operations. Often the very men who insist most strongly that cities should be liberal in settling with the public utility companies, are loudest in their condemnation of municipalities for not being efficient and businesslike in the mangement of public enterprises.

We are now entering upon a critical era. Our cities face unmeasured future responsibilities. We must set our house in order for eventualities that may come quickly. It behooves every well-wisher of civic democracy to do all in his power to develop intelligence, consistent purpose, justice, absolute candor and administrative courage in the management of public utility enterprises which have already been municipalized; and to secure the adoption of wise and adequate measures to facilitate the acquisition and operation of the street railways of the country under legal, financial and administrative conditions conducive to success in public operation, with or without public ownership.

\title{
WHAT WILL BECOME OF THE GOVERN- MENT HOUSING?
}

\author{
BY RICHARD S. CHILDS \\ New York City
}

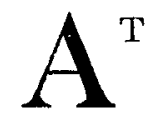

$\mathrm{T}$ THE end of the war Uncle Sam has on his hands a dozen wooden cities ranging in population from 1,500 to 30,000 . These are the temporary towns erected in remote wilderness locations for the employes of explosives plants. These towns in most cases are being promptly depopulated, the plants dismantled and the houses and dormitories taken apart and sold for use in other locations.

The completed, permanent villages have been constructed only in those places where there is reasonable certainty of a market for the houses after 